Proc. Estonian Acad. Sci. Biol. Ecol., 2006, 55, 2, 137-148

\title{
Scots pine (Pinus sylvestris L.) and its habitat in Muraka bog under the influence of wastes from the Narva power plants (North-East Estonia)
}

\author{
Katri Ots $^{\mathrm{a}^{*}}$ and Vaike Reisner ${ }^{\mathrm{b}}$ \\ ${ }^{a}$ Department of Ecophysiology, Institute of Forestry and Rural Engineering, Estonian University of \\ Life Sciences, Viljandi mnt. 18B, 11216 Tallinn, Estonia \\ ${ }^{\mathrm{b}}$ Institute of Forestry and Rural Engineering, Estonian University of Life Sciences, Kreutzwaldi 5, \\ 51014 Tartu, Estonia
}

Received 15 December 2005, in revised form 22 March 2006

\begin{abstract}
Needle mass per area, nutrients, and stem radial increment of Scots pines (Pinus sylvestris L.) growing in a bog in the influence zone of the Narva thermal power plants, NE Estonia, were studied. Needles growing in the crown at a height of $3 \mathrm{~m}$ from ground had a considerably greater mass per area than those at a height of $1.5 \mathrm{~m}$. From 1892 to 1963 the radial increment of pines in the bog was relatively stable. Great changes occurred in 1964-2004: sudden decreases of radial increment alternated with periods of increasing radial increment. Needles growing in the middle part of the crown exposed to pollution fluxes have 1.1-1.4 times higher nutrient concentrations than needles formed at a lower level of the crown. In the control area in SW Estonia away from industrial pollutants no statistically significant differences in the mineral content between needles growing in different crown layers were observed.
\end{abstract}

Key words: air pollution, element concentrations, needle mass, peatland, Pinus sylvestris L., radial increment.

\section{INTRODUCTION}

Estonia is situated in a region where precipitation exceeds evaporation, and relatively plain surface structure and badly filtrated base favour excessive water accumulation, which causes the formation of swamps. Bogs have preserved in other European countries only fragmentarily due to intensive human activity. Therefore, it is important to preserve the diverse and peculiar bog pine forests in Estonian scenery. The bog pine forest is one of the number one priority forest habitat types of the European Union Nature directive (Council directive 92/43/EEC of 21 May 1992 on the conservation of natural habitats and wild fauna and flora), one of the goals of which is to preserve natural diversity.

\footnotetext{
*Corresponding author, katri.ots@rmk.ee
} 
Peat fields of different size cover $22.5 \%$ of the Estonian territory (Orru et al., 1992). There are 400000 hectares of bogs in Estonia, which form approximately $9 \%$ of the Estonian territory and $40 \%$ of the territory of mires (Seemen et al., 2000). Therefore, Estonia is one of the mire-richest areas in Europe. In Finland there are more mires, they cover approximately a third (31\%) of Finland's territory (Lappalainen, 1996). According to geobotanical charting, there are 136000 ha of bog pine woods in Estonia, which is approximately a tenth of our forest-covered area (Laasimer, 1965).

Although Estonian bog pine forests are primitive biotopes on which human activity has so far had little impact, the intensifying industry is becoming a threat to the existence of bogs. The alkaline deposition from the Narva thermal power plants in North-East Estonia affects the sensitive ombrotrophic bog ecosystems isolated from mineral soil and groundwater and which get all their nutrients from the atmosphere (Pensa et al., 2004; Kaasik \& Ploompuu, 2005). Under the influence of alkaline solids emitted from Kunda cement plant for decades, the $\mathrm{pH}$ of the water in Iila and Varudi bogs in the same area has risen to 5-6 and the peat moss has disappeared (Karofeldt \& Ploompuu, 1989). The $\mathrm{pH}$ of naturally acidic bog water rises and enrichment with nutrients causes changes in plant species composition (Ploompuu, 1997; Kaasik et al., 2001).

Further research is needed in the area of bog pine forests, which are comparatively rare in European scale, to clarify their state and development. The condition of pines is best reflected in radial and height increment and in the changes of biomass formation (Schweingruber et al., 1985; Cook \& Innes, 1989; Mandre \& Ots, 1999; Ots, 2002).

The main economic activities influencing Estonian mires have been agriculture, forestry, peat harvesting, oil shale mining, power generation, and urban development (Vasander et al., 2003). Due to the growing human impact there have been changes in the bogs' water conditions and chemical composition of the ecosystem; those changes have in turn been influencing the growth and development of the bog pine forests. The present paper discusses the state of the Scots pine (Pinus sylvestris L.) community of Muraka bog located in the influence zone of the Narva thermal power plants (North-East Estonia). As control, Tolkuse bog, which is relatively unpolluted (South-West Estonia), was used. Differences in peat, water, and pine needle chemistry, needle size, and radial growth were ascertained by comparative analyses.

\section{MATERIAL AND METHODS}

\section{Study area}

The study was carried out in North-East Estonia in the influence area of the Narva thermal power plants (PPs) (Muraka bog, polluted area) and in SouthWest Estonia (Tolkuse bog, area relatively free of pollution), approximately $230 \mathrm{~km}$ from the Narva PPs (Fig. 1). Muraka bog belongs to the Ramsar list of internationally important wetlands. It is approximately 9000-10 000 years old 


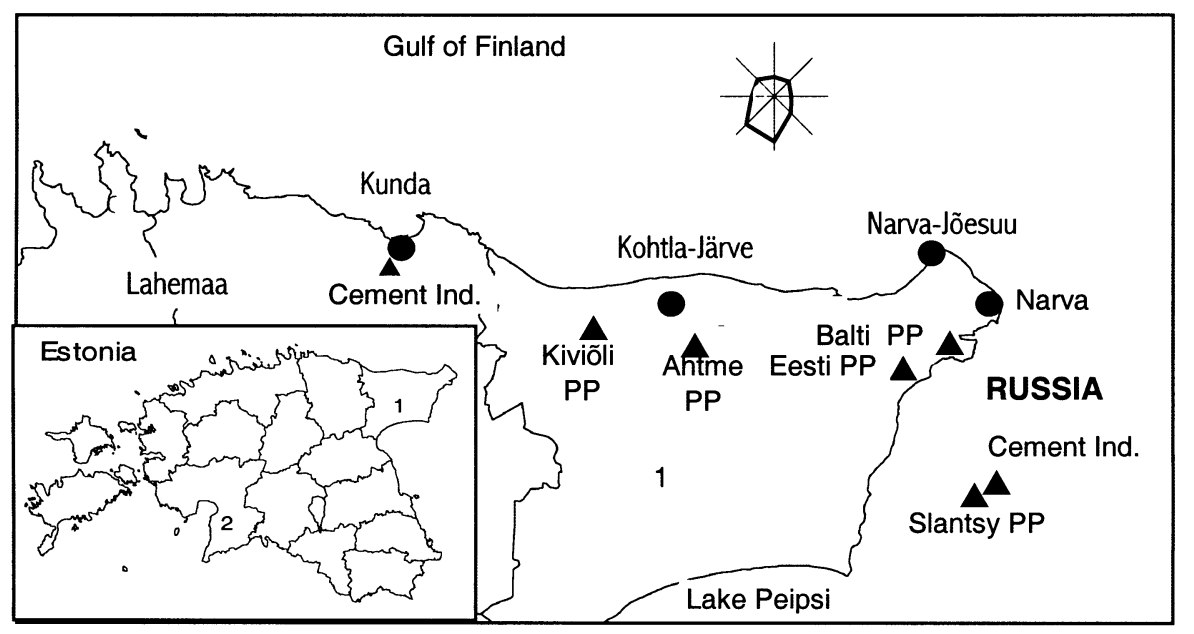

Fig. 1. Schematic map of the location of sample plots (1 - Muraka bog, 2 - Tolkuse bog) and pollution sources in the study area.

and is part of the ancient natural landscape characteristic of North-East Estonia. It consists mainly of mire landscape, of which $60 \%$ is bogs. In the central part of the bog the thickness of the peat layer is 5-7 $\mathrm{m}$ (Müür, 2003).

Tolkuse bog in Pärnu County (South-West Estonia), which is about 6500 years old, is the largest and the central part of the Rannametsa-Soometsa landscape reserve located on the Pärnu Lowland. Its total area is $55 \mathrm{~km}^{2}$, of which fens cover $34.7 \mathrm{~km}^{2}$ and bogs $16.2 \mathrm{~km}^{2}$. This bog is unique in the whole Europe being one of the few lagoon mires that have developed to bog stage.

According to Lõhmus's (2004) classification, the studied pine stands belong to the bog site type. The Scots pines are 125-140 years old in Muraka bog $\left(h=15 \pm 0.5 \mathrm{~m}, d_{1.3}=24 \mathrm{~cm}\right)$ and $90-95$ years old in Tolkuse bog $(h=12 \pm 0.4 \mathrm{~m}$, $\left.d_{1.3}=15 \mathrm{~cm}\right)$.

\section{Sampling and analyses}

To estimate changes in the growth environment, samples of peat $(n=5)$, bog water $(n=5)$, Scots pine needles $(n=30-200)$, and radial increment cores $(n=60)$ were collected in the two bogs in autumn 2004. The concentration of N, $\mathrm{P}, \mathrm{K}, \mathrm{Ca}$, and $\mathrm{Mg}$ in the peat and $\mathrm{N}, \mathrm{P}, \mathrm{K}$, and $\mathrm{Ca}$ in Scots pine needles were analysed by the Agricultural Research Centre at Saku, Estonia. The $\mathrm{pH}$ of bog water and that of the peat in the top layer $(10-30 \mathrm{~cm}$ below the surface) were determined with a $\mathrm{pH}$-meter (Mettler Toledo MP 220).

For determining the mass per area (ratio of needle dry mass to needle area, $\mathrm{g} \mathrm{m}^{-2}$ ) of current-year (formed in 2004) and 1-year-old (formed in 2003) needles in different layers of a pine crown, sample branches $(n=3)$ were taken from the crowns of bog pines $(n=20-30)$ at heights of $1.5 \mathrm{~m}$ and $3 \mathrm{~m}$ from the ground in August 2004. 
Two radial increment cores were taken from Scots pines $(n=30)$ at the northern and southern sides of trees at a height of $1.3 \mathrm{~m}$ with an increment borer in autumn 2004. The radial increments were measured with the help of a personal computer and scanner; the results were processed with the package WinDENDRO ${ }^{\mathrm{TM}}$ (2001). Only trees with an approximately circular cross-section were accepted and the material was cross-dated.

For statistical analyses ( $t$-test) the programs Systat 10.0 and Excel 9.0 were used.

\section{Air pollution}

The major pollution sources in North-East Estonia are two oil-shale-fired thermal power plants near the town of Narva. The Balti PP was commissioned in 1959 and the Eesti PP in 1969. The marked rise in the production of electric power in the 1970s polluted the air not only in North-East Estonia but also in the whole area of the Gulf of Finland as the flue gas from the high stacks (Balti PP $150 \mathrm{~m}$, Eesti PP $300 \mathrm{~m}$ ) spread over hundreds of kilometres (Anttila et al., 1996). A characteristic feature of thermal power plants is high concentration of sulphur compounds and fly ash in the flue gas emitted into the atmosphere form the stacks (Ots, 1999; Agrawal \& Singh, 2000). The large amount of dust in the emissions from oil-shale-fired power plants is due to a high concentration of ash (40-50\%) in the oil shale used as fuel (Häsänen et al., 1995). According to Kisel (1999), the ash concentration in Estonian oil shale may be as high as $80 \%$ of the amount of fuel.

Analysis of 30 elements in the emissions from the Narva PPs showed that in 1992 the following elements were emitted in the largest amounts: $\mathrm{Ca}(36000 \mathrm{t})$, $\mathrm{K}(9700 \mathrm{t}), \mathrm{Al}(8400 \mathrm{t}), \mathrm{S}(7300 \mathrm{t})$, and $\mathrm{Fe}$ (4500 t) (Häsänen et al., 1995). As a result of reduced production of electric power, improved technologies, and increased efficiency, pollution from the power plants has decreased during the last ten years. Reduced atmospheric pollution as compared to the early 1990s is indicated also by lowered concentrations of heavy metals in mosses (Keskkond 1997, 1999). According to data by Kaasik (1997), in parallel with decreasing emissions of pollutants also pollution fluxes have been falling in North-East Estonia; however, this fall has not been as great as that of known emissions. The impact of alkaline air pollution on ecosystems will persist due to pollution fluxes as well as the dust accumulated in the environment.

\section{RESULTS AND DISCUSSION}

\section{Bog water and peat}

Bogs are obviously the most sensitive terrestrial associations to alkaline air pollution because (1) they are naturally very acidic; (2) they get their mineral nutrients from the air, and (3) they are poor in mineral matter. Due to specific metabolism of peat moss $\left(\mathrm{H}^{+}\right.$ions are released $)$, the $\mathrm{pH}$ of the bog water is always acidic (pH 2-4) (Karofeld \& Ploompuu, 1989). In Varudi bog affected by 
Kunda cement plant the $\mathrm{pH}$ of the upper layers of bog water is 6.5 (Ploompuu \& Brock, 2003). Changes in bog water characteristics can already partly be seen by eye. The water that in normal conditions is dark brown is in more polluted bogs brightened and clear; in addition to decreasing acidity of bog water, the content of mineral matter in water is elevated. In Niinsaare and Liivjärve bogs affected by Ahtme, Balti, and Eesti PPs the pH of bog water was up to 6 (Karofeld, 1987). The average $\mathrm{pH}$ of the water samples from Muraka bog was $5.62 \pm 0.18$. The average $\mathrm{pH}$ of bog water samples collected on the same day from Varudi bog affected by Kunda cement plant was $8.29 \pm 0.01$. Comparison shows that Muraka bog is not affected by the alkaline pollution from Narva PPs as much as Varudi bog is affected by Kunda cement dust.

Analysis of the samples showed that the $\mathrm{pH}$ of peat in Muraka bog was in the range 4.9-5.2 and in Tolkuse bog in the range 3.3-4.2. In addition to unfavourable hydrological conditions, bogs have one more factor hindering tree growth - shortage of nutrients in bog peat. The nutrient concentrations of Muraka bog peat (\% of dry mass) varied as follows: total $\mathrm{N} 0.9-1.8$, total P $0.04-0.83$, total K 0.15-0.3, Ca 0.24-0.65, and Mg 0.08-0.15. It can be seen that in Muraka bog, affected by the Narva PPs, peat contains essentially larger amounts of stored $\mathrm{P}, \mathrm{K}$, and $\mathrm{Ca}$ (differs accordingly 2.7, 5.3, and 1.9 times) than in Tolkuse bog (Fig. 2). The $\mathrm{Cu}$ content in the peat moss of Muraka bog was between 5.7 and $12.7 \mathrm{mg} \mathrm{kg}^{-1}$, being up to 4 times higher than the $\mathrm{Cu}$ content in forest soil in the area affected by power plants (Ots, 2001).

In Estonian bog soils the amount of $\mathrm{N}$ and $\mathrm{P}$ that plants can assimilate is not sufficient for satisfactory growth of trees (Seemen et al., 2000). To stimulate tree

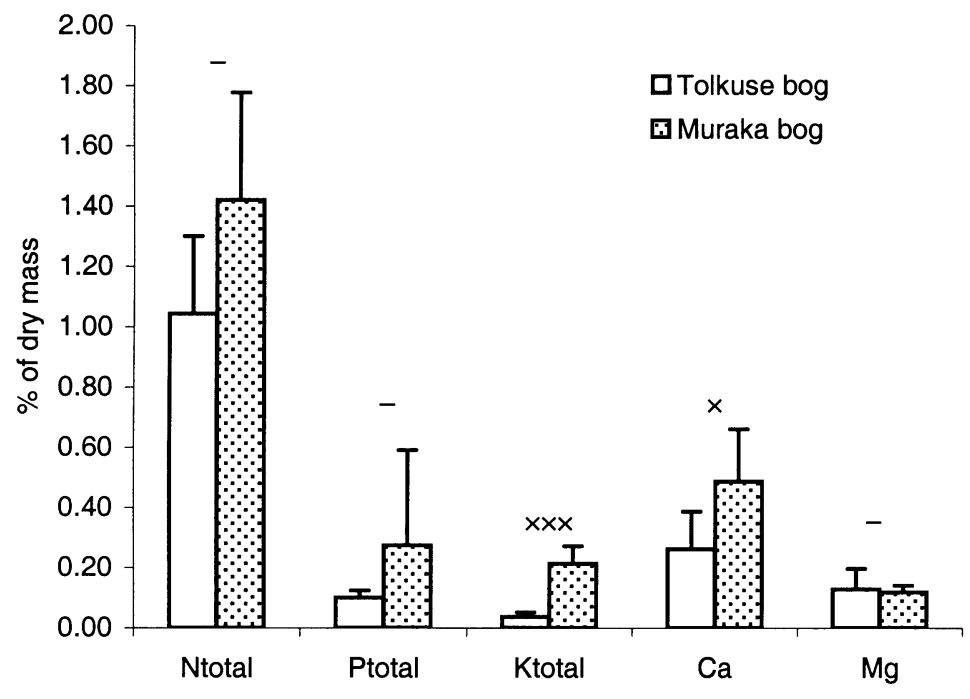

Fig. 2. Concentration of chemical elements $($ mean $\pm \mathrm{SD}$ ) in peat in Muraka (North-East Estonia, polluted) and Tolkuse (South-West Estonia, unpolluted) bogs. For calculating statistical differences the two-sided $t$-test was used; $\times p \leq 0.05, \times \times \times p \leq 0.001,-p>0.05$. 
growth, oil shale ash has been applied as a fertilizer on bogs. Combined with $\mathrm{P}$ and $\mathrm{K}$ fertilizers oil shale ash did stimulate tree growth (Valk, 2005). Vertical distributions of total $\mathrm{N}, \mathrm{P}, \mathrm{K}, \mathrm{Ca}$, and $\mathrm{Mg}$ in a $0-60 \mathrm{~cm}$ surface peat layer were studied at 80 pine mire sites in southern Finland (Laiho et al., 1998). The compaction of peat had compensated for the effect of the processes removing nutrients from the soil (increased tree stand uptake, leaching); for $\mathrm{Ca}$ and $\mathrm{Mg}$ to a lesser degree than for the other nutrients $(\mathrm{N}, \mathrm{P}, \mathrm{K})$. It was concluded that the $\mathrm{N}$, $\mathrm{P}$, and $\mathrm{K}$ profiles did not show changes that would be likely to affect site productivity, whereas the net loss of $\mathrm{Ca}$ and $\mathrm{Mg}$ may cause problems in the longer term.

\section{Needle mass per area}

To describe the state of a tree's crown, one possibility is to study different crown layers. Vertical variation of leaf area in the tree crown has been studied by several researchers (Osawa, 1990; Tullus \& Tamm, 1992; Vares, 2000). Studies have shown that the vertical distribution of the assimilation area in a tree crown depends on several factors such as site type, forest density, light conditions, tree age, crown height, structure, etc. Based on $t$-test, the needle mass per area differed significantly between the current-year and 1-year-old needles. The average mass per area of current-year needles (formed in 2004) in the crown at a height of $1.5 \mathrm{~m}$ from the ground was $0.1 \mathrm{~g} \mathrm{~m}^{-2}$ and that of 1-year-old needles (formed in 2003) at the same crown layer was $0.16 \mathrm{~g} \mathrm{~m}^{-2}$ in Muraka bog. Needles growing in the crown at a height of $3 \mathrm{~m}$ from the ground in Muraka bog had a considerably greater mass per area: current-year needles $0.2 \mathrm{~g} \mathrm{~m}^{-2}$ and 1-year-old needles $0.26 \mathrm{~g} \mathrm{~m}^{-2}$ (Fig. 3).

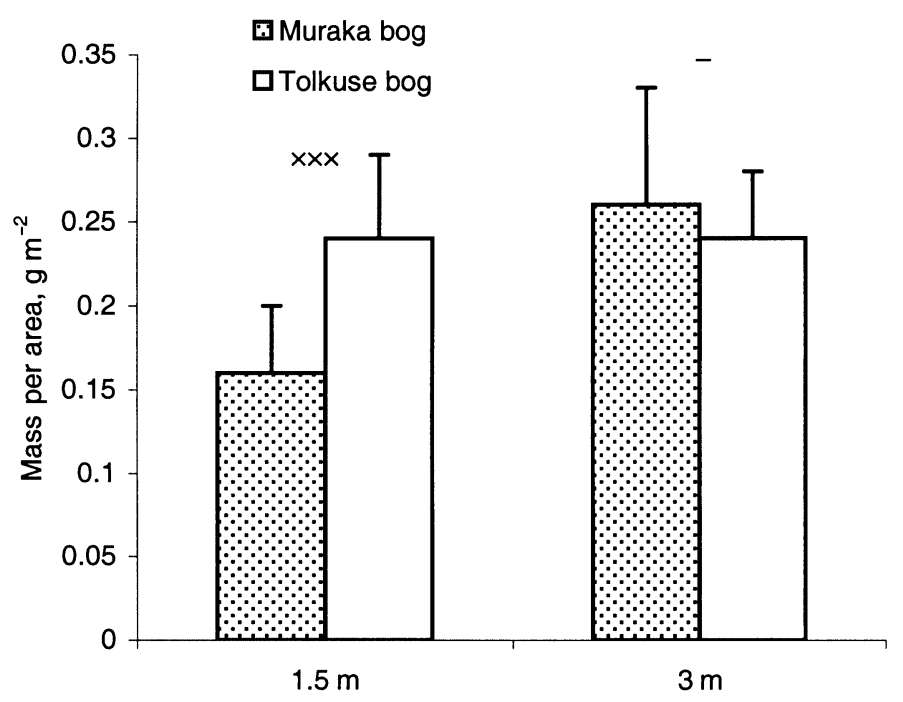

Fig. 3. Mass per area of 1-year-old bog pine needles (mean \pm SD) at different crown layers. For calculating statistical differences the two-sided $t$-test was used; $\times \times \times p \leq 0.001,-p>0.05$. 
In Tolkuse bog no differences between needle mass per area in different crown layers were observed (Fig. 3). The mass per area of 1-year-old needles differed statistically $(p<0.001)$ between the studied crown layers in Muraka bog, but in current-year needles no statistically significant difference was found. The differences between the two bogs at the height of $1.5 \mathrm{~m}$ from the ground were statistically significant $(p<0.001)$ (Fig. 3).

\section{Radial increment}

In Estonia radial increment cores have been taken from pines over 300 years old growing in bogs (Läänelaid, 2001). In bogs pines do not grow much older. Limits are established by hard growth conditions, especially by the fact that the thickening of the peat layer leaves tree roots deeper and deeper in airless bog soil.

Figure 4 depicts the radial increment of pines in Muraka and Tolkuse bogs. From 1892 to 1963 the radial increment was relatively stable, but in 1964-2004 great variation occurred: sudden decreases of radial increment alternated with periods of increasing increment. Fly ash pollution in North-East Estonia began with the launching of the Narva PPs: Balti PP was launched in 1959 and Eesti PP in 1969. Similarly to findings by Kaasik \& Ploompuu (2005), the growth of Muraka bog pines has essentially fastened (Fig. 4). Before the Eesti PP was put into operation, the average radial increment of pines was $0.6 \pm 0.2 \mathrm{~mm}$ in Muraka bog and $1.0 \pm 0.22 \mathrm{~mm}$ in Tolkuse bog. In 1970-2004 the radial growth of pines in Muraka bog increased on average 1.3 times while the radial growth of

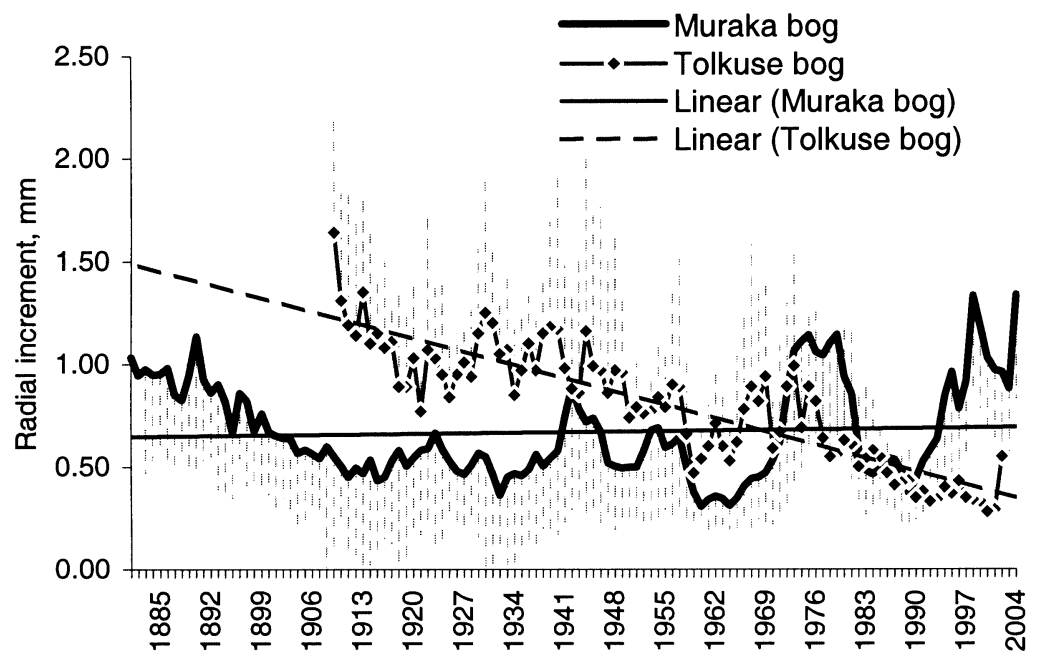

Fig. 4. Radial increment (mean $\pm \mathrm{SD}$ ) and its trend of Muraka and Tolkuse bog pines. 
pines in Tolkuse bog decreased on average 1.8 times (Fig. 4). Pensa and co-workers (2004) concluded that in the area where the air is polluted by the oil shale industry (thermal power plant and chemical factories) the increase in the growth of bog pines is partly caused by the fertilizing effect of fly ash, which can induce drastic changes in these ecosystems. Bog plants obtain all the necessary nutrients only from the atmosphere via precipitation and dust deposition (Karofeld \& Ploompuu, 1989). Therefore, the improved growth of pines may be caused by increased influx of airborne nutrients.

During the last four decades the growth conditions of bog pines have changed, the fastened growth of pines has been noticed also in other, less studied uninfluenced bogs, although the growth increment should slow down when trees become older. This may be caused by climate change but also the spreading of pollutants has to be considered: bog associations formed on substrate poor in nutrients is very sensitive to mineral pollution. Forest stands around power plants in bogs, including Muraka bog, have thickened into forests, while unpolluted bog pine stands have maintained their previous density (Kaasik \& Ploompuu, 2005).

\section{Mineral elements}

The content of mineral elements in trees depends on numerous factors, such as species, the growth and development stage of the plant, place of growth, etc. The fly ash carried to the marshes from the thermal power plants and the oil shale industry changes the plants' growth environment making it more alkaline and thus influences their formation. In the trees growing in the influence area of power plants the content of $\mathrm{As}, \mathrm{Ca}, \mathrm{Hg}, \mathrm{K}, \mathrm{Mg}, \mathrm{Na}, \mathrm{S}, \mathrm{Se}, \mathrm{Sr}$, and $\mathrm{Zn}$ increases, but that of $\mathrm{Cu}$ and $\mathrm{Mn}$ decreases (Braniewski \& Chrzanowska, 1988; Maňkovská, 1998). High concentrations of elements accumulated in the peat in the influence zone of the Narva PPs and large amounts of $\mathrm{P}, \mathrm{K}$, and $\mathrm{Ca}$ in needles were observed (Fig. 5). Lack of nitrogen causes a decrease in the leaf area and also in the net assimilation per leaf area unit (Raid, 1996). This may explain the larger dimensions of needles with higher $\mathrm{N}$ concentrations (needle mass per area) in the crown at a height of $3 \mathrm{~m}$ compared with needles growing in the lower level (Fig. 5). Potassium, which activates many enzymes, regulates the water regime in plants and stabilizes their metabolism (Mohr \& Schopfer, 1995), is among the dominant elements in the alkaline fly ash emitted into the atmosphere by the Narva PPs. Needles growing in the middle part of the crown well exposed to pollution fluxes in Muraka bog contained 1.3 times more $\mathrm{P}$ and $\mathrm{K}$ and 1.4 times more $\mathrm{Ca}$ than needles formed in the lower level of the crown (Fig. 5). In unpolluted Tolkuse bog no statistically significant differences in the mineral content of needles growing in different crown layers were observed (Fig. 5). The concentration of $\mathrm{P}, \mathrm{K}$, and Ca was respectively 1.6-2.1 $(p<0.01), 1.3-1.9(p<0.01)$, and 1.3-2.1 $(p<0.001)$ times higher in Muraka bog 1-year-old pine needles compared with Tolkuse bog pine needles. 


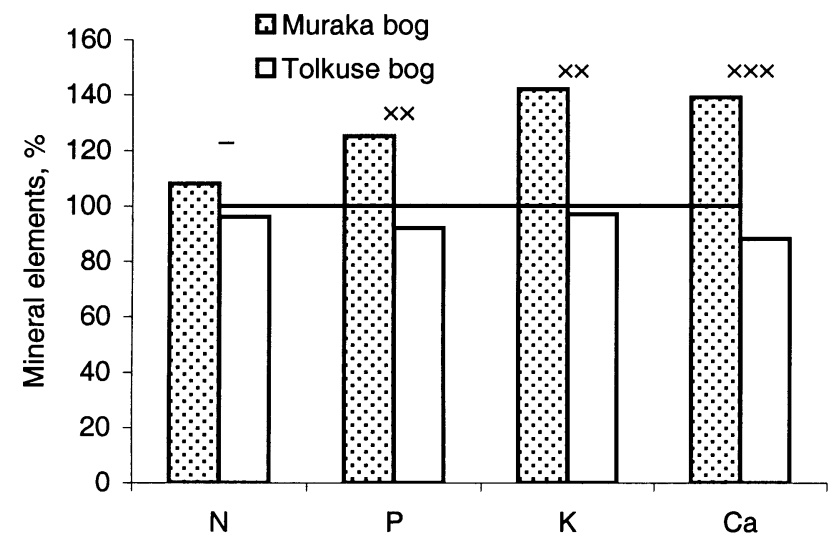

Fig. 5. Concentrations of mineral elements in 1-year-old bog pine needles in the middle part of the crown $(3 \mathrm{~m})$ in relation to those in the lower part of the crown $(1.5 \mathrm{~m})$. For calculating statistical differences the two-sided $t$-test was used; $\times \times p \leq 0.01, \times \times \times p \leq 0.001,-p>0.05$.

\section{CONCLUSIONS}

The metabolism in Muraka bog has for decades been affected by fly ash rich in alkaline nutrients emitted from the high stacks of Ida-Virumaa thermal power plants. Acidic environment characteristic of bog has become more alkaline. Changes can be noticed in the state of bog water, peat, and vegetation. Comparative analysis showed that pine needle mass per area is greater at a height of $3 \mathrm{~m}$ than at a height of $1.5 \mathrm{~m}$ in polluted Muraka bog. This can be explained with better light conditions in the middle part of the crown. The larger content of elements in needles growing higher in the crown can indicate a better growth due to the nutrient-rich fly ash. Further investigations are needed in this field to specify the relationships.

\section{ACKNOWLEDGEMENTS}

The authors wish to thank the Ministry of Education and Research (project No. 0432153s02) and the Estonian Science Foundation (grant No. 5986) for financial support to this research.

\section{REFERENCES}

Agrawal, M. \& Singh, J. 2000. Impact of coal power plant emission on the foliar elemental concentrations in plants in a low rainfall tropical region. Environ. Monit. Assess., 60, 261282.

Anttila, P., Ojanen, M., Puhakka, M., Vuorisalo, T. \& Frey, T. 1996. Hapestavad saasted. In Globaalsed keskkonnaprobleemid, pp. 158-160. Eesti Loodusfoto, Tartu. 
Braniewski, S. \& Chrzanowska, E. 1988. Effect of dust from electro-filters of different industrial works on the vegetation. Sci. Papers Krakow Agric. Acad. For., 18, 146-167.

Cook, E. \& Innes, J. 1989. Tree-ring analysis as an aid to evaluating the effects of air pollution on tree growth. In Biologic Markers of Air-Pollution Stress and Damage in Forests, pp. 157-168. National Academy Press, Washington.

Häsänen, E., Aunela, L., Kinnunen, V., Larjava, K., Mehtonen, A., Salmikangas, T., Leskelä, J. \& Loosaar, J. 1995. Emission factors of bulk and trace elements from oil-shale fueled power plants. In Proc. 10th World Clean Air Congress. Emission and Control, Espoo, Finland, May 28-June 2, 1995, pp. 57-60.

Kaasik, M. 1997. Kas õhu saastamine Kirde-Eestis on vähenenud? In Kaasaegse ökoloogia probleemid (Frey, T., ed.), pp. 77-83. Tartu, Estonia.

Kaasik, M. \& Ploompuu, T. 2005. Põlevkivimaa rabad kasvavad metsa. Eesti Loodus, 1, 42-45.

Kaasik, M., Ploompuu, T., Sõukand, Ü. \& Kaasik, H. 2001. The impact of long-term air pollution to the sensitive natural ecosystems: a case study. In Proceedings of the 7th International Conference on Environmental Science and Technology. Ermoupolis (Lekkas, T. D., ed.), pp. 381-387. Syros, Greece.

Karofeld, E. 1987. Kurtna järvestiku rabade looduslike tingimuste ja taimkatte dünaamikast viimastel aastakümnetel. In Kurtna järvestiku looduslik seisund ja selle areng, pp. 133-139. Tallinn.

Karofeld, E. \& Ploompuu, T. 1989. Mis teist saab, Virumaa rabad? Eesti Loodus, 3, 136-141.

Keskkond 1997. 1999. Keskkonnaministeeriumi Info- ja Tehnokeskus, Tallinn.

Kisel, E. 1999. Põlevkivielektrijaamade suurinvesteeringud on suunatud keskkonna kaitsele. Keskkonnatehnika, 3, 24-25.

Läänelaid, A. 2001. Rabamänd mäletab mitut sajandit. Eesti Loodus, 2-3, 104-105.

Laasimer, L. 1965. Eesti NSV taimkate. Tallinn.

Laiho, R., Sallantaus, T. \& Laine, J. 1998. The effect of forestry drainage on vertical distributions of major plant nutrients in peat soils. Plant Soil, 207, 169-181.

Lappalainen, E. 1996. Global Peat Resources. Jyskä.

Lõhmus, E. 2004. Raba kasvukohatüüp. In Eesti metsakasvukohatüübid, pp. 68-69. Tartu.

Mandre, M. \& Ots, K. 1999. Growth and biomass partitioning of 6-year-old spruces under alkaline dust impact. Water Air Soil Pollut., 114, 13-25.

Maňkovská, B. 1998. The chemical composition of spruce and beech foliage as an environmental indicator in Slovakia. Chemosphere, 36(4-5), 949-953.

Mohr, H. \& Schopfer, P. 1995. Plant Physiology. Springer Verlag, Berlin.

Müür, R. 2003. Muraka looduskaitseala. Eesti Loodus, 11, 5-6.

Orru, M., Veldre, M. \& Shirokova, M. 1992. Eesti turbavarud. RE Eesti Geoloogia Keskus, Tallinn.

Osawa, A. 1990. Reconstructed development of stem production and foliage mass and its vertical distribution in Japanese larch. Tree Physiol., 7, 189-200.

Ots, A. 1999. Sada aastat põlevkiviga muretu. Energeetika Uudiskiri, 1, 10.

Ots, K. 2001. Kaltsiumi ja vase sisaldusest hariliku männi tüvepuidus Narva Elektrijaamade mõjupiirkonnas. Metsanduslikud uurimused, 35, 52-58.

Ots, K. 2002. Impact of Air Pollution on the Growth of Conifers in the Industrial Region of Northeast Estonia. Doctoral dissertation. OÜ Vali Press, Põltsamaa, Tartu.

Pensa, M., Liblik, V. \& Jalkanen, R. 2004. Temporal changes in the state of a pine stand in a bog affected by air pollution in northeast Estonia. Water Air Soil Pollut., 159, 87-99.

Ploompuu, T. 1997. Rabade taimekoosluste teisenemine leeliselise tolmusaaste toimel Kunda ümbruses. In Kaasaegse ökoloogia probleemid (Frey, T., ed.), pp. 177-184. Tartu.

Ploompuu, T. \& Brock, A. 2003. Marker elements for water movement in bog peat from deposited air pollutants. In Ecohydrological Processes in Northern Wetlands. Selected Papers of International Conference \& Educational Workshop. Tallinn, Estonia, 30 June-4 July 2003 (Järvet, A. \& Lode, E., eds), pp. 283-289. Tartu University Press, Tallinn, Tartu. 
Raid, L. 1996. Toiteelementide dünaamika männiokastes. Metsanduslikud uurimused, 27, 84-91. Schweingruber, F. H., Kontic, R., Niederer, M., Nippel, C. A. \& Winkler-Seifert, A. 1985. Diagnosis and distribution of conifer decay in the Swiss Rhone Valley. In Establishment and Tending of Subalpine Forest. Research and Management (Turner, H. \& Tranquillini, W., eds), pp. 189-192. Eidg. Anst. Forstl. Versuchswes., 270.

Seemen, H., Pikk, J. \& Valk, U. 2000. Unikaalne metsanduslik katseala Rae rabas. Akadeemilise Metsaseltsi Toimetised III (Meikar, T., ed.), pp. 95-112. Tartu.

Tullus, H. \& Tamm, Ü. 1992. A characterization of needle mass in middle-aged pine stands. For. Stud., 25, 60-86 (in Russian).

Valk, U. 2005. Eesti rabad. OÜ Halo Kirjastus, Tartu.

Vares, A. 2000. Vertical variation of leaf size and weight per area in 21-year-old black alder plantations. For. Stud., 32, 73-77.

Vasander, H., Tuittila, E.-S., Lode, E., Lundin, L., Ilomets, M., Sallantaus, T., Heikkilä, M.-L. \& Laine, J. 2003. Status and restoration of peatlands in northern Europe. Wetlands Ecol. Manage., 11, 51-63.

\title{
Narva elektrijaamade saaste mõju harilikule männile (Pinus sylvestris L.) ja kasvukohale Muraka rabas (Kirde-Eesti)
}

\author{
Katri Ots ja Vaike Reisner
}

Tulenevalt kasvavast inimmõjutusest on toimunud muutused rabade veerežiimis ja ökosüsteemi keemilises koostises, mis omakorda on mõjutanud rabamännikute kasvu ja arengut. Artiklis on käsitletud hariliku männi (Pinus sylvestris L.) seisundit õhusaastele tundlikus rabakoosluses: Narva elektrijaamade mõjupiirkonnas Muraka rabas (Kirde-Eesti) ja suhteliselt saastepuhtas Tolkuse rabas (Edela-Eesti). Võrdlusanalüüsidega on selgitatud muutused turbas ning rabavees ja männiokaste pindtiheduses, minaraalainete sisalduses ning radiaalses juurdekasvus.

Muraka raba toiterežiimi on aastakümneid mõjutanud Ida-Virumaa kõrgete korstnatega soojuselektrijaamadest suurtele aladele emiteeruv leeliseline toitainerikas lendtuhk. Rabale iseloomulik happeline keskkond on muutunud seetõttu leeliselisemaks. Täheldatavad on muutused rabavee ning -turba ja rabamändide morfoloogias ning füsioloogilises seisundis. Täheldatav on, et Narva elektrijaamade mõjupiirkonda jääva Muraka raba turbas on Tolkuse rabaga (asub Edela-Eestis tööstuslikest saasteallikatest eemal) võrreldes ladestunud oluliselt suuremas koguses fosforit, kaaliumi ja kaltsiumi (erinevus vastavalt 2,7, 5,3 ja 1,9 korda) (joon 2).

Võrdlusanalüüs näitab, et Muraka raba männiokaste pindtiheduse näitajad on maapinnast $3 \mathrm{~m}$ kõrgusel võras kasvavatel okastel paremad kui maapinnast 1,5 m kõrgusel. See on seletatav paremate valgustingimustega rabamänni võra keskosas, kuid võras kõrgemal kasvavate okaste suurem elementide sisaldus võib viidata kokkupuutele toitainerikka lendtuhaga ja seega paremale kasvule. 
Kui aastatel 1892 kuni 1963 võis täheldada suhteliselt stabiilset Muraka raba mändide radiaaljuurdekasvu trendi, siis perioodil 1964-2004 toimus hüppeline muudatus: puude juurdekasvu järsud langusperioodid vaheldusid jõudsate kasvuperioodidega.

Halb lämmastikuga varustatus kutsub esile nii lehepinna kui ka netoassimilatsiooni vähenemise lehepinna ühiku kohta (Raid 1996), mis võib selgitada suurema lämmastikusisaldusega okaste suuremaid mõõtmeid (okaste pindtihedus ja jämedus) maapinnast $3 \mathrm{~m}$ kõrgusel võras, võrreldes võra alumises kihis kasvavate okastega Muraka rabas. Muraka rabas saastevoogudele hästi eksponeeritud võra keskosas kasvavad okkad sisaldavad 1,3 korda rohkem fosforit ning kaaliumi ja 1,4 korda rohkem kaltsiumi kui võra alumises kihis formeerunud okkad (joon 5). Tolkuse rabamändide erinevates võrakihtides kasvavate okaste minaraalainete sisalduses statistiliselt usaldatavat erinevust pole täheldatud. 